\title{
Why, sometimes, primaries? Intraparty democratization as a default selection mechanism in German and Spanish mainstream parties
}

\author{
Javier Astudillo \\ Universitat Pompeu Fabra, Spain \\ Klaus Detterbeck \\ University of Göttingen, Germany
}

\begin{abstract}
In many Western democracies, political parties have started to open to members the selection of their leaders. While most studies focus on the introduction of this new selection method, its subsequent practice is still understudied. The article contributes to our still limited knowledge of this process by looking at two multilevel countries, Germany and Spain, where the mainstream parties have sometimes organized membership ballots, especially at the regional level, for leadership selection. Thanks to two original databases on party conferences and membership ballots, the article analyzes the background of this process and reviews the most common explanations offered by the literature. It shows that they are not held when parties want to regain power, or party chairs seek their nomination, as commonly believed, but when there are intraparty leadership disputes.
\end{abstract}

\section{Keywords}

Party primaries, leadership selection, intraparty divisions, Germany, Spain

\section{Introduction}

The plebiscitary democratization of leadership selection is a growing phenomenon in many older and newer democracies as part of a broader process of opening party decision-making processes to all members and even sympathizers (Cross and Pilet, 2015; Sandri et al., 2015). The effects of more inclusive selectorates on membership activism, internal power balances and electoral performance, as well as consequences at the political system level, have attracted much academic interest in recent years (Hazan and Rahat, 2010; Pilet and Cross, 2014).

However, besides these effects, their very introduction and subsequent practice are in and of themselves intriguing. Several scholars have argued that party elites voluntarily relinquish their monopoly over the selection of leaders because "membership ballots"1 actually reinforce party leadership autonomy (Mair, 1997) or help parties select leaders with better electoral chances (Adam and Merrill, 2008). In either case, it is unclear why "in some cases few contests have taken place since their adoption" (Sandri et al., 2015: 188).

Given the novelty of the democratization of the leadership selectorate, some parties such as the Canadian Liberals, the Danish Social Democrats, and the Dutch Christian Democrats, to mention just a few, present only one such experience. As a result, we do not know whether membership ballots will be repeated or how frequently they will be used. In some parties, such as the Sozialdemokratische Partei Deutschlands (SPD) at the federal level, the first occasion was also the last one (see also Gherghina, 2013). Drawing on novel data from two European countries with longer experience, this article is one of the first to

Paper submitted 4 December 2017; accepted for publication 23 July 2018

Corresponding author:

Javier Astudillo, Universitat Pompeu Fabra, Ramon Trias Fargas, 25-27, Barcelona 08005, Spain.

Email: javier.astudillo@upf.edu 
analyze what happens after their first practice. It focuses on intraparty conflict for explaining cases in which parties make only erratic use of membership ballots. We thus contribute to the still-limited knowledge of this key aspect of contemporary party politics.

We look at the German and Spanish two-decade experience of using membership ballots for selecting party leadership in general. In these two countries, as it is usually the case in continental Europe, parties tend to separate the process for selecting their "party chair" from the one for nominating their "prime ministerial candidates," also referred to in the literature as "electoral leaders" or "top candidates" (Spitzenkandidat in German, candidato a presidente in Spanish). Traditionally, internal party organs were the venues for deciding on both matters. However, in the last decades, and mainly at the regional level, German and Spanish parties have occasionally allowed grassroots participation in the selection of both party officials and top candidates.

Both countries are classic parliamentary democracies with multilevel structures, composed of Länder and Comunidades Autónomas. According to the Regional Authority Index elaborated by Hooghe et al. (2016), in 2010, Germany and Spain were among the most decentralized countries in a sample of 80 countries. In addition, the comparison of these two countries also allows us to analyze the extent to which the age of a democracy influences the direct participation of party members in the leadership selection process. In this sense, scholars have suggested that political parties in older and newer democracies differ in their internal structure and functioning (Van Biezen, 2003). Parties in newer democracies tend to give less salience to the party on the ground and concentrate power in the party leadership, especially in the central office. They also prioritize an electoralist strategy over organizationally penetrative strategies. It is however unclear which type of democracy, if any, should be more likely to practice the use of membership ballots (Lisi et al., 2015).

In this work, we have restricted our analysis to the major established parties in the left and right camps: the SPD, Christlich Demokratische Union-Christlich-Soziale Union (CDU-CSU), Partido Socialista Obrero Español (PSOE), and Partido Popular (PP). These are the parties whose selection of prime ministerial candidates is the most consequential. They have controlled the premiership of both the national and most of the regional governments for the last 30 years.

While for the study of the national level we have used data available in the literature and the media, for the study of the regional branches we have built two original databases for the two distinctive selection processes of party chairs and top candidates in the German Länder and the Spanish Comunidades Autónomas from 1990 up through 2016. The information on the way regional party chairs and top candidates are selected comes from different sources: parties' websites, newspapers, party documents and press, and published studies on parties and regional elections.

The article is divided in three parts. First, we review the academic debate on membership ballots and party primaries, and develop our main hypotheses on the causal link between internal party conflict and the employment of these plebiscitary instruments. In the second part, we trace the process of their introduction and practice in these two countries in the last 25 years at the national and regional levels. Here we highlight the main differences between German and Spanish parties as well as their similarities. In the third part, we try to explain one of their most important similarities: the erratic use of "party primaries" in both countries. The conclusion will summarize our findings.

\section{The debate on intraparty plebiscites}

While party researchers have interpreted more inclusive modes of internal decision-making in quite different ways, Barnea and Rahat (2007) have offered an analytical model that integrates most of the existing explanations. According to them, the process of internal democratization results from an interplay between developments at three levels: the political system, the party system, and the intraparty level. In order to understand why parties have shifted powers to ordinary members, scholars have combined explanations related to these three different levels. However, debates still exist about the specific weight that each level has in this development, and the actual causal mechanism at play at each level (see Lisi, 2010).

With respect to the political system, significant changes in society and in the political environment are seen as drivers of organizational innovation. First, the erosion of representative linkages between parties and society has undermined party legitimacy (Katz and Mair, 1995). Electoral volatility, popular mistrust, and membership decline are interpreted as signs of de-alignment that threaten party survival. At the same time, processes of cognitive mobilization have taken place, in which citizens have acquired stronger political knowledge, become more critical and asked for stronger rights of political participation (Norris, 1999). But as parties are still in need of an active membership for reasons of democratic legitimacy, societal presence, and political recruitment, leadership groups have been willing to open up decision-making processes for attracting new supporters (Detterbeck, 2013).

At the level of the party system, individual parties may experience strong pressures to adapt to competitive dynamics. In particular, electoral setbacks may convince party leaders of the need for party renewal and more democratic internal processes. Parties that have lost governmental office or experienced serious electoral decline are expected to engage more seriously with organizational reform (Cross, 2013; Scarrow, 1999). In a similar vein, parties that have been in opposition for a long time may 
desperately seek some new impetus for escaping their diaspora (Chiru et al., 2015). Finally, isomorphism and ideology may be important factors for democratizing leadership selection (Pilet and Cross, 2014). The former implies that parties are following successful innovations of their competitors, while the latter assumes that parties are becoming more democratic internally in accordance with their programmatic visions.

Without denying the importance of these factors, other scholars have placed more emphasis on intraparty dynamics. Some organizational agents seek to improve their relative position within the internal distribution of power (Panebianco, 1988). The first, and most wellknown, explanation at this level is the one offered by the cartel party thesis (Katz and Mair, 1995). Its advocates have called attention to the "paradoxical role of party membership" (Mair, 1997: 146): while members seem to matter less in running routine party affairs, and parliamentary elites and party staff have acquired more autonomy, in many parties members' voice is directly sought by party elites on specific occasions.

Mair tries to solve this puzzle by arguing that the empowerment of ordinary members is paralleled by the marginalization of the mid-level activists. The delegates at party conferences and in party committees, who constitute the more active and organized layer of the party on the ground, lose their effective control of the party politics. They are the real losers of intraparty plebiscites. The membership at large, passive and atomized, will be far less likely to seriously challenge the wishes of the party elites. Thus, by circumventing the party activists, direct democracy within parties can actually help to enhance leadership power.

Recently, however, Kamahlioglu et al. (2009) extensively elaborated another explanation, supported in passing by other scholars, that also focuses on intraparty factors. Based on the Latin American experience, they consider that in contrast to legislative offices, which can be divided among parties or groups, top party leadership is the most valuable and least divisible office. This can cause considerable internal turmoil when parties are divided between groups that are likely to suffer from low levels of mutual trust, with the losing factions undermining the winners' strategies and policies or threatening to leave the party. As a result, to avoid internal Pyrrhic victories, the conflicting factions seek a mechanism that makes it difficult for the losing factions to reject supporting the eventual winners. Membership ballots can be such a mechanism, given the high democratic legitimacy the public and the media attribute to such procedures. In their view, then, intraparty plebiscites are most likely to occur when there is considerable disagreement among party elites about whom the party should select as next party leader.

These factors have mainly been suggested to explain the adoption of intraparty plebiscites, and some of them have already been used for Germany (Detterbeck, 2013; Scarrow, 1999) or Spain (Barberà et al., 2015; Ramiro, 2016). We also consider that some of the factors acting at the party system and intraparty levels could also explain the subsequent (rare) practice of membership ballots. For example, plebiscitary instruments could be called only when parties suffer dramatic electoral defeats, and/or when the party leaders have encountered "rebellious" activists at previous party conferences.

In this article, we seek to explore empirical evidence for the saliency of intraparty conflict in triggering the use of membership ballots in German and Spanish parties. More specifically, we argue that they are only employed by party elites as a default mechanism in situations of internal disagreement. Following Kamahlioglu et al. (2009), rational party actors may choose to give the members a say when they have not been able to come up with a consensus solution on leadership positions. Under such circumstances, they may prefer the current loss of control to the divisive effects of an open leadership battle. Yet, this often comes at the price of having competitive races, with several contenders and rather tight races, whose results are difficult to predict. Therefore, membership ballots remain rare events. Or, to put it the other way around: the more internal turmoil there is, the more membership ballots are needed to pacify factionalism and to keep conflict down to a manageable level.

\section{A comparison of German and Spanish membership ballots}

Germany and Spain are two countries where parties usually separate the process for selecting the "party chair," or the formal leader of parties' central office (called Parteivorsitzende in Germany, Presidentes or Secretarios Generales in Spain), from the process of nominating their "top candidate." In the first case, in both countries, mainstream parties traditionally employed, at the national and regional levels, conferences of delegates who represented the membership. In these conferences, German and Spanish parties regularly tried to avoid open leadership contests (Cross, 2013). Party executives or smaller circles of party notables usually agreed upon a candidate who was then presented to the party conference for "coronation." In the case of the selection of "top candidates," German parties again employed party conferences, whereas in Spain, until the introduction of party primaries, the selection was done by party executive organs (Astudillo, 2014). In this nomination process, party chairs could be selected or had to accept the choice of another top candidate with stronger voting appeal (Detterbeck, 2013).

Spanish and German mainstream parties also have in common that they are vertically integrated organizations in which the regional party branches are interlocked with their national organizations. ${ }^{2}$ In Germany, the branches of 
statewide parties possess autonomy to govern their own affairs (self-rule) while also being strongly involved in the decision-making processes of their federal party (shared rule) (Detterbeck, 2013). The level of self-rule and shared rule of the Spanish major parties, by contrast, is lower. Regional branch autonomy tends to be limited in practical terms by the capacity of central organs to veto regionally based decisions on most salient organizational, electoral, and policy issues (Pallares et al., 2015).

The introduction of membership ballots in Germany has usually been presented as part of a general process of organizational reforms to attract new members and/or stimulate rank-and-file internal participation, such as gender quotas in party bodies and public representative organs and the opening of party structures (Jun et al., 2009; Scarrow, 2015). The German mainstream parties have thus used membership ballots for the selection of party chairs and top candidates, as well as for selecting legislative candidates in single constituencies, and deciding on a few policy issues and organizational innovations (Decker and Küppers, 2015; Neumann, 2013).

As under the German party law, national and regional party conferences have the final say over the selection of their respective leadership, membership ballots are only held as "consultative votes" (Mitgliederbefragung). That said, party conferences tend to confirm the results of membership ballots. At the national level, the SPD has been the only mainstream party that has undertaken a "consultative" membership ballot for the selection of its Parteivorsitzender, and only on one occasion, in 1993. After this ad hoc procedure, the Social Democrats returned to the more traditional modus of conference voting. With respect to the selection of its top candidates, since 1993, the SPD statutes provide for an intraparty plebiscite on the party candidate for chancellorship, but it has yet to be implemented. ${ }^{3}$

Most of these organizational innovations were also implemented in the regional party branches. The 1989 CDU federal party conference called on their subnational party units to develop and experiment with reform proposals. Meanwhile, the SPD started the process from above by establishing a federal party reform project group ("SPD 2000") in 1991. As a result, both the SDP and CDU Land branches have changed their party statutes to allow for consultative membership ballots on party chairs and/or top candidates. In addition, since the 1990s, there have been four instances when parties in government organized a full membership vote for determining the successor of a premier who had resigned in office (see Detterbeck, 2013: 282). Finally, Figure 1 shows that, contrary to earlier analyses (Scarrow, 1999), membership ballots have not actually experienced a sustained decline over time at the regional level.

In the case of Spain, the introduction of membership ballots in the mainstream parties has been until recently almost a Socialist Party affair, and restricted to selecting

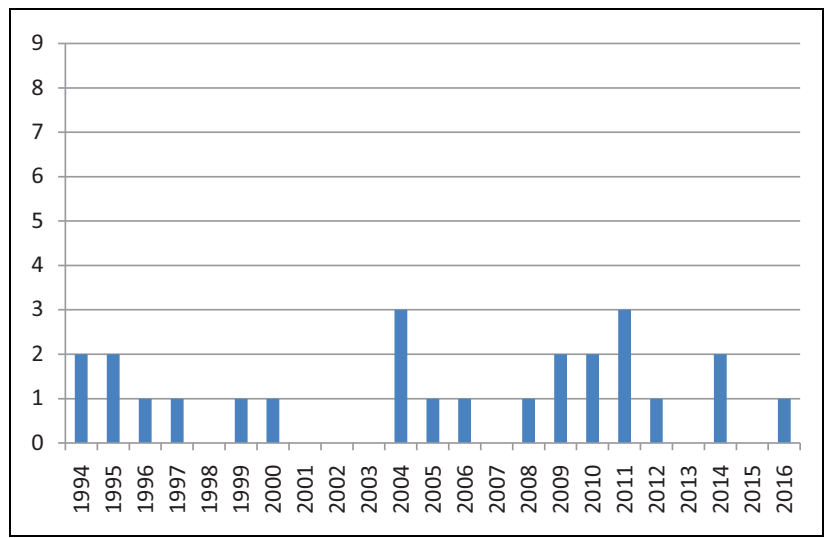

Figure I. Absolute number of regional membership ballots by year, Germany.

Source: Authors' own data sets.

the top candidate (Barberà et al., 2015). ${ }^{4}$ In the PSOE, innovation in the selection of party leadership has taken place in two moments. The first period of innovation and practice started in the mid-1990s, after the Socialists lost most of the regional governments they had controlled as well as the national government, after 14 years in power. In 1997, the 34th national PSOE conference opened the selection of mayoral candidates to the rank-and-file members, and made it optional for regional and national top candidates. One year later, the first primaries for the selection of the candidates for the premiership of the regional and national governments were held. After again losing the general elections of 2000, the 35th national PSOE conference finally established in their statutes the primaries as the formal procedure for selecting their top candidates at the national and regional level. National and regional party chairs, however, continued to be selected by their respective party conferences (Astudillo, 2015).

This conference also laid out regulations for the requisites to participate as voter and aspirant, and the cases in which the holding of primary elections would be canceled. The PSOE internal regulations established that only party members could vote, while aspirants had to obtain either the support of the party executive organs or endorsement by a high percentage of the membership ( $10 \%$ for the national primaries and $15 \%$ for the regional ones). The actual elections among members would be canceled if just one aspirant ran (except in two regions), the party established pre-electoral coalitions with other parties, or-in the case of subnational primaries - they were suspended by the national party organs. Finally, although not totally excluded, primaries were discouraged if the party held executive office.

The second period of innovation and practice started in the early 2010s (see Figure 2), after the PSOE again lost most of its regional governments and the national government. In its 38th party conference in February 2012, the 


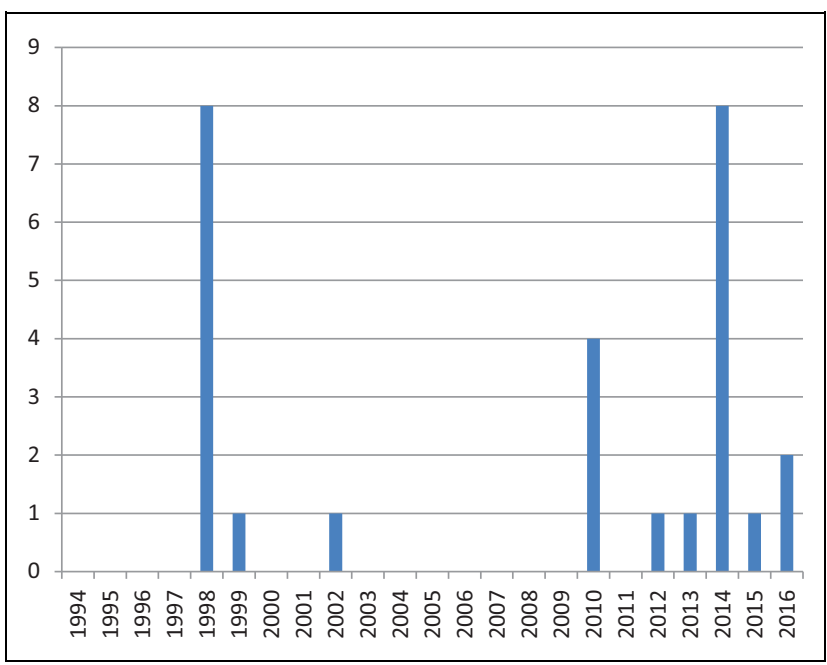

Figure 2. Absolute number of regional membership ballots by year, Spain.

Source: Authors' own data sets.

party decided to open the primaries for the selection of the national top candidate to nonparty members, while making it optional at the regional level. One year later, the Socialists of Galicia went a step further and unilaterally decided to organize a "consultative" membership ballot for the selection this time of their party chair. After initial opposition by the national organization, this innovation became the formal procedure at the national and regional level. In July 2014, for the first time in the PSOE's history, party members elected directly their national Secretario General. In addition, the level of membership endorsement was lowered for both the selection of top candidates and party chairs $(5 \%$ at the national level and $10 \%$ at the regional level), though the previous reasons for the cancellation of the elections were maintained.

As expected, there are some significant differences in the type and practice of membership ballots between the two countries. Since the mid-1990s, the SPD and CDU have opened the selection of legislative and executive candidates, premiers, and party chairs to the participation of members. Initially, the PSOE only opened this process for the selection of top candidates, and primaries have never been used to decide on the region premiership when incumbent premiers quit their office. However, in the 2010s, when the PSOE finally opened the selection of party chairs to its members, it also opened the selection of its top candidates to nonmembers, a move yet to be undertaken by the German parties.

Another important difference is that in Germany membership ballots can only have a "consultative" status, in accordance with the 1967 party law, while the flexibility of the Spanish law lets parties establish membership ballots as, in principle, the formal procedure. Nevertheless, in the PSOE, as in other parties in countries such as the United
Kingdom, Canada, and Ireland, to mention just a few, its statutes establish reasons for not holding them.

Notwithstanding these differences, implementation of ballots in Spain and Germany presents striking similarities. First of all, Table 1 shows that both countries present an ideological bias in the use of membership ballots. The center-left parties, the SPD and the PSOE have held more membership ballots than the center-right parties. It is also worth noting that even in Germany, where the use of membership ballots by both left and right parties has been more balanced at the regional level, only in 3 of the 16 Länder have both parties held membership ballots, and in 2 of them there was a temporal lag of more than 15 years. In Spain, up to 2016, only in the Balearic Islands had both parties held membership ballots. Therefore, we cannot talk of a contagious effect (isomorphism) of their use among mainstream parties.

Table 1 also shows that in both countries, party organizational reforms concerning the selection of party leaders have been more effective at the regional party level. In both countries, most regions have experienced membership ballots at least once. In Germany, they have been held in 11 out of the 16 Länder, whereas in Spain, they have been held in 12 out of the 17 Comunidades Autónomas. In those German regions where membership ballots took place, Bremen has held five elections, the highest number, while in four Länder this has only happened once. ${ }^{5}$ In Spain, three membership ballots is the highest number held, a figure reached by five Comunidades Autónomas, while three have held just one.

Yet, although the PSOE has availed itself of membership ballots more than German parties to select its top candidates, in the end, it is still as rare an event in Spain, at both the national and regional levels, as it is in Germany (see Table 1). The exact mechanisms for not holding elections are, however, somehow different in each country. In Germany, as membership ballots have not been made compulsory, party executives have remained strong gatekeepers in the selection process. It is mainly their decision whether to present a consensus candidate at a party convention or to arrange for a membership ballot with several candidates. In the PSOE, membership ballots are in principle the statutory procedure for the selection of top candidates and, since 2014 , of party chairs. But, given that in all but a few regions they can be circumvented if only one candidate runshighly likely given the stringent requisites for contesting - they are used almost as infrequently as in Germany.

Some observers and scholars have thus spoken of an erratic movement toward intraparty democratization in both countries (Detterbeck, 2013; Ramiro, 2016). Party primaries were regarded by party elites in the PSOE as a decorative "Chinese vase." $\mathrm{In}$ both countries, "party leaders have shown much more interest in publicizing than actually employing the new channels [for members' participation]" (Scarrow, 1999: 349). Nevertheless, at least 
Table I. Membership ballots: Absolute number and frequency by party, level, and type of leader selected since their first implementation (year in brackets) until 2016.

\begin{tabular}{lllll}
\hline & SPD & CDU-CSU & PSOE & PP \\
\hline National party chair & I, I2.5\% (1993) & Never used & I** $(2014)$ & Never used \\
National top candidate & Never used & Never used & I, I6.7\% (1998) & Never used \\
National premier & Never used & Never used & Never used & Never used \\
Regional party chairs & $7,12.5 \%(1994)$ & $4^{+}, 3.6 \%(2004)$ & $6 * *(2013)$ & $2^{* *}(2010)$ \\
Regional top candidates & $8,10.3 \%(1995)$ & $3,3.8 \%(1994)$ & $19,21.3 \%(1998)$ & Never used \\
Regional premiers & $3,20.0 \%(1995)$ & $\mathrm{I}^{+}, 5.6 \%(2004)$ & Never used & Never used \\
\hline
\end{tabular}

Source: Authors' own data sets.

Note: SPD: Sozialdemokratische Partei Deutschlands; CDU-CSU: Christlich Demokratische Union-Christlich-Soziale Union; PSOE: Partido Socialista Obrero Español; PP: Partido Popular.

**Percentage is only given if 10 or more years passed since first implementation of membership ballots.

+The same vote was used to select a party chair and a regional premier.

sometimes, membership ballots are held. So, why and when is that?

\section{Why, sometimes, intraparty plebiscites at the regional level}

In the explanatory part, we focus first on the use of regional primaries for selecting top candidates. They are the only type of membership ballot that, until the early 2010s, has been shared by both countries, and their time span permits testing several hypotheses about their (rare) use. We have analyzed 347 processes of top candidate selection in the 33 German and Spanish regions for our four parties from the first year primaries were used in each country to 2016. In a second explanatory analysis, we reintroduce the study of the selection of party chairs.

\section{First explanatory analysis: Party system pressure or internal conflicts?}

Thanks to our database on candidate selection, we address the debate between party system pressure and internal party conflict. Here we do not distinguish, however, whether the internal conflicts are the result of struggles between the mid-level activists and party elites or of factional divisions among the latter. Our data set does not allow us for directly distinguishing the type of conflict.

In the first three regression models, our dependent variable is the holding or not of primary elections for selecting top candidates in any given election. Our first set of three independent variables focuses on the party system level and tries to test the hypothesis that parties call primaries in order to regain public support, and ultimately the government. ${ }^{7}$ First, we study if the party had lost governmental office since the previous elections. In some other cases, parties have been in the opposition for many years. This can trigger experimentation with primaries as a way to come to power. We have thus studied the number of years the party had been in the opposition. Finally, we have also measured parties' electoral evolution in the two previous elections as indicative of whether there has been a sustained drop of public support. ${ }^{8}$ We test the hypotheses that, when parties have lost power, have been many years in the opposition, or have seen their electoral appeal deteriorate among citizens, it is more likely that primary elections will be held to select top candidates for the next regional elections.

Our second set of independent variables tries to assess the effects of internal conflicts within the regional branches (intraparty dynamics). In concrete terms, we analyze whether the dynamics of selecting party chairs later affects the likelihood of holding primaries for selecting top candidates. As we can generally assume that party chairs tend to occupy their office for a short period of time when facing internal disagreements (Ware, 1996), we use as a first proxy of internal conflicts the frequency of party chair rotation in the legislative term before each regional election. The average duration of a regional legislative period is 3.5 years in Spain and 4.5 years in Germany, and our variable goes from 0 rotations up to 5 . In more than half of our cases, in the previous legislative term, there was no change of the party chair; in around 36\% of cases, there was one change; in around $9 \%$ of cases, there were two changes; and in less than $1 \%$, there were three or more changes. We have thus created a threedummy variable for 0,1 , and 2 or more rotations where 0 rotations is our reference category.

There is also a widespread public perception, often driven by the media, that parties are internally divided when several contenders aspire to become party chair, or when the "consensus" aspirant faces a substantial number of negative or blank votes (Boucek, 2009). Therefore, our second proxy is a dummy variable that measures if the chairs of the regional branch, before the regional elections took place, had faced competitors in their selection at their party conference, or received less than $80 \%$ of the vote of delegates if selected unopposed. Our hypotheses are that, the higher the number of rotations of regional party chairs, or their having faced other aspirants and/or substantial 
Table 2. Factors explaining regional party primaries.

\begin{tabular}{|c|c|c|c|c|}
\hline & Model I (all) & Model 2 (all) & Model 3 (all) & Model 4 (first time only) \\
\hline No. years in opposition & $-0.023(0.036)$ & - & $-0.012(0.037)$ & $-0.034(0.039)$ \\
\hline Lost government & $-0.313(0.665)$ & - & $-0.148(0.690)$ & $-0.626(0.752)$ \\
\hline Previous electoral evolution & $-0.153(0.07 I)^{*}$ & - & $-0.151(0.086)$ & $-0.269(0.095)^{* *}$ \\
\hline One rotation of party chairs & - & $0.878(0.494)$ & $0.757(0.572)$ & $0.228(0.678)$ \\
\hline Two rotation or more of party chairs. & - & $2.655(0.717)^{* * *}$ & $2.874(0.85 \mathrm{I})^{* *}$ & $\mathrm{I} .575(0.820)$ \\
\hline Party chair elected with opposition & - & $1.056(0.481)^{*}$ & $1.363(0.605)^{*}$ & $0.917(0.609)$ \\
\hline Country & $0.097(0.715)$ & $0.084(0.491)$ & $-0.033(0.674)$ & $-0.619(0.649)$ \\
\hline Center-left party & $2.754(0.913)^{* *}$ & $2.839(0.709)^{* * *}$ & $3.004(0.946)^{* * *}$ & $2.794(0.911)^{* *}$ \\
\hline Previous party primaries & $-1.608(0.873)$ & $-0.206(0.962)$ & $-1.019(1.029)$ & - \\
\hline Year election & $-0.024(0.037)$ & $-0.008(0.035)$ & $-0.025(0.039)$ & $-0.134(0.05 \mathrm{I})^{* *}$ \\
\hline Incumbent top candidate & $-2.770(0.953)^{* *}$ & $-1.721(0.752)^{*}$ & $-2.011(0.957)^{*}$ & $-2.696(1.061)^{*}$ \\
\hline Constant & $44.812(74.38 I)$ & $12.318(71.088)$ & $45.444(79.916)$ & $265.322(102.151)$ \\
\hline$N$ & 325 & 322 & 315 & 259 \\
\hline
\end{tabular}

Source: Authors' own data sets.

$* p<0.05 ; * * p<0.01 ; * * p<0.001$.

vote of protest during party conferences, the higher the likelihood of calling party primaries to select the party's regional top candidate.

We have introduced as controls the following set of variables. First, we control for the year in which the elections took place, since there could be a temporal association between some of the previous independent variables and the holding of primaries. Second, we also control for the presence of primaries in the previous regional elections. Holding primaries could in itself influence the organization of primaries for the next elections. We have also controlled for the country where elections took place to control for the particularities of each country, and introduced a dummy variable about the center-left or center-right character of the party to test if the ideological difference between these parties shown in Table 1 is statistically significant. Finally, we have controlled if the top candidate was an incumbent regional premier.

Given that we treat each party's top candidate selection process in each regional election as a separate observation, we have conducted a cross-sectional time-series analysis. Hence, we have estimated a series of random effects logistic regression models to test for temporal sensitivity. In these models, the standard errors of the estimates are corrected to take into account repeated observations for each party's regional top candidate selection process across time. In the first two models, we test separately each set of hypotheses, and in the third, model all of them. ${ }^{9}$

Our first model shows that two of the variables that try to grasp the party's desire to recover public support and/or government are not statistically significant (see Table 2). ${ }^{10}$ Only the previous electoral evolution is statistically significant. Among the control variables, we can see that there is not a statistically significant variation between Germany and Spain, but the ideology of the party does matter. This means that center-left parties are not more prone to hold primaries because they are in a weaker electoral position than their center-right rivals. Finally, holding the regional presidency also reduces the probability of holding primaries in the next elections.

By contrast, the second model shows that our proxies of internal conflicts have the right sign and are statistically significant. In concrete, having changed the party chairs two or more times since the last regional elections affects the likelihood of holding primaries for the next elections. It also matters having them selected in a contested party conference. Furthermore, ideology continues to matter. Again, we can reject that this is the case because center-left parties are more prone to experience internal conflicts than centerright parties.

Finally, in the third model, we control if the effects of internal party instability are influenced by the recent expulsion from government, the number of years in the opposition, or the previous electoral evolution. Again, the variables referring to internal problems are statistically significant and with the sign expected. In terms of predicted probabilities, holding the rest of the variables on their mean, a party whose party chair was not changed since the previous regional elections had a probability of holding primaries of around $7 \%$, if changing once of $11 \%$, but when two or more times the probability reaches $30 \%$. Equally, having selected the party chair with competitors or substantial opposition increases the probability of holding primaries by 9 percentage points. Finally, the probability of a center-left party holding primaries is 13 percentage points higher than for a center-right party. And holding the presidency of regional government reduces the probability of holding primaries by 9 percentage points.

The fact that the explanatory role of being in the opposition for many years, leaving the government, or suffering a continuous hemorrhage of votes is not supported by our 
data has been a bit surprising for us. After all, it seems too coincidental that the two most significant moments of innovation in PSOE's party rules coincided with the Socialists' simultaneously losing the national government and most of its regional governments. Therefore, we have tested whether some of these variables could explain the first time primaries are used in both countries. Model 4 in Table 2 shows our results. We can see now that the previous electoral evolution does affect the likelihood of holding primaries for the first time, and the intraparty factors stop being relevant.

\section{Second explanatory analysis: Can membership ballots be instruments to control mid-level activists?}

Controlling for other factors, we have seen that, when there are divisions and instability in the parties' regional central office, it is more likely that they hold primaries to select their regional top candidate. Still, we do not know whether the internal divisions are indicative of conflicts with the mid-level activists or driven by factionalism. Some previous detailed qualitative analyses have rejected the first explanation for the internal democratization. For example, Scarrow (1999: 349) rejected that membership ballots in Germany were "disguised attempts to disempower party activists."

It is not easy to prove this with our data sets. However, the cartel thesis suggests that party conferences are more difficult to control by the party elite than membership ballots. Mid-level activists, the most organized layer of the party on the ground represented in those conferences, are less likely according to this theory to endorse the party elite's policies and candidates than are ordinary members (Katz and Mair, 1995). Is there any empirical evidence of this?

To undertake this analysis, and in order to have a bigger number of cases of a direct participation of party members, we now compare party conferences and membership ballots for both selecting party leaders and nominating top candidates from 1994 up through 2016. We first compare the degree of competitiveness - measured by both the number of candidates and the closeness of the contest - of membership ballots and party conferences. With respect to the number of candidates, according to our data set on regional party conferences, since 1990 around $81 \%$ of the German regional party chairs and $73 \%$ of the Spanish ones have been "coronated."11 By contrast, membership ballots most often feature two or more aspirants.

Closer contests are also more frequent in membership ballots than in party conferences in both countries. In membership ballots, the winner obtained a very similar share (around $62 \%$ of the votes on average) in both countries. By contrast, at the German regional party conferences, the winner obtained around $84 \%$ of the vote on average, and in Spain $79 \%$.
Table 3. Percentage of party chairs defeated in their reselection bid and/or seeking the nomination as top candidate since 1994 . $^{\text {a }}$

\begin{tabular}{lccc}
\hline & $\begin{array}{c}\text { In party } \\
\text { conferences }\end{array}$ & $\begin{array}{c}\text { In membership } \\
\text { ballots }\end{array}$ & $\begin{array}{c}\text { Total } \\
\text { defeated }\end{array}$ \\
\hline CDU-CSU & 2.8 & 66.7 & 4.6 \\
SPD & 3.0 & 50.0 & 5.7 \\
PSOE & 3.3 & 26.7 & 7.9 \\
Total & 3.0 & 37.5 & 5.9 \\
\hline
\end{tabular}

Source: Authors' own data sets.

Note: CDU-CSU: Christlich Demokratische Union-Christlich-Soziale Union; SPD: Sozialdemokratische Partei Deutschlands; PSOE: Partido Socialista Obrero Español; PP: Partido Popular. Differences between selection mechanisms statistically significant at $95 \%$.

${ }^{\text {a } P P}$ excluded.

Table 4. Factors explaining defeats of party chairs seeking reselection as chairs and/or nomination as top candidates. ${ }^{a}$

\begin{tabular}{lc}
\hline Selection by membership ballot & $5.052(\mathrm{I} .52 \mathrm{I})^{* * *}$ \\
$\begin{array}{l}\text { Type of leadership sought (party chair vs. top } \\
\quad \text { candidate) }\end{array}$ & $-1.614(\mathrm{I} .468)$ \\
Center-left party & $0.225(0.909)$ \\
Country & $0.859(0.937)$ \\
Year of selection & $-0.007(0.053)$ \\
Constant & $10.947(107.577)$ \\
$N$ & 290
\end{tabular}

Source: Authors' own data sets.

Note: PP: Partido Popular.

$* p<0.05 ; * * p<0.01 ; * * * p<0.001$.

${ }^{\text {a } P P}$ excluded

Second, we now analyze whether the proportion of party chairs that have been defeated when running - either seeking reselection as chairs or aspiring to the nomination as top candidate - varies significantly according to the selection mechanism. Table 3 clearly shows that, notwithstanding party differences, this seems to be the case. ${ }^{12}$ Membership ballots do not seem to be a good instrument for the elites to control the reselection of party chairs or the nomination of top candidates. This finding is confirmed even when controlling for type of leadership sought (party office or candidate), ideology, country, and year of selection (see Table 4). ${ }^{13}$ Our findings fit also with the conclusion of Ramiro (2016: 128) for Spain that in this country party officials mistrusted this selection mechanism. ${ }^{14}$

Finally, in the Spanish case, it is also difficult to explain why, if ordinary party members are docile selectors, the party felt the need to establish in the party rules stringent requisites for running, or the protection they offered to the incumbent candidates, as we saw previously.

In conclusion, from these analyses, it is difficult to defend the suggestion that membership ballots are held whenever party elites are sure ordinary members are going to endorse and legitimize their wishes. 


\section{Conclusions}

In this article, we have studied two multilevel countries, Germany and Spain, as representative of "second-" and "third-wave" democracies, to explain the use of membership ballots for the selection of party officials and top candidates following their voluntary introduction more than two decades ago. Given the novelty of plebiscitary democratization in many countries, current studies have mainly focused on its adoption.

Unsurprisingly, as Germany and Spain are two different countries, we have found significant differences in the regulation, type, frequency, and timing of membership ballots. Notwithstanding these differences, we have also found striking similarities. In both countries, membership ballots in general, and party primaries in particular, have been more frequent at the regional level than at the national level. Perhaps the salience of politics at the national level constitutes an incentive for party factions to find a consensus candidate and avoid gambling with membership ballots. This needs further research.

But in both countries, even at the regional level, their use has been quite erratic since their initial introduction. The current consensus argues that changes in leadership and candidate selection methods result from the interplay among three levels: the political system, the party system, and the intraparty level. We have therefore analyzed whether factors playing at the party system and intraparty levels can further explain what happens afterward.

We have three main conclusions. First, introducing reforms is not the same as implementing them regularly, and each phenomenon may have its own set of explanatory factors. The cases of regional Germany and Spain have let us see, for example, how some factors which seem to explain the first use of primaries, such as the previous electoral evolution, do not seem to explain their subsequent practice.

Second, in our cases, the ideological position of parties seems to be a relevant factor for the use of plebiscitary instruments. Our specific statistical analyses on the use of party primaries show that this is not because German and Spanish center-left parties are in a weaker electoral situation, are excluded from government, or are more prone to internal divisions than center-right parties. After controlling for these factors, the former are still more prone to hold primaries. International comparisons have, however, downplayed the role of ideology. We consider that further research should clarify when and why ideology seems to matter in some countries but not in others.

As the third main conclusion, party primaries, the type of membership ballots most employed in both countries, are held when there are divisions and instability in the parties' organizations. In addition, previous qualitative analyses and the results of our comparison of party conferences and membership ballots suggest that this internal instability is not the result of conflicts with party activists.

Leaving aside the different types of internal conflict, our study strongly defends that party elites are the driving force, not only in introducing membership ballots, as already suggested (Sandri et al., 2015: 188), but in their later use as well. Notwithstanding this, we must be careful of overstating the argument regarding strategic use by party elites. If we mean that membership ballots for selecting organizational and top candidates are only called to legitimize party elites' wishes and wield power without restraint, we are rather misguided. They can instead be seen as default mechanisms to end internal stalemate. Party elites decide to give the members a say when they have not been able to come up with a consensus solution. Holding membership ballots implies a loss of control for party elites, which is the reason why they try to circumvent them when they can. But sometimes they cannot.

Last but not least, a few words must be said about the possibility of extrapolating our results. First, we have only analyzed leadership selection. The selection of legislative candidates by primaries is another matter, as explained by Kenig et al. (2015b). In addition, we think our results could be generalized to those parties which occasionally hold membership ballots for selecting party leaders and/or top candidates. Our results are obtained from studying mainstream parties. They do not necessarily apply, for example, to new antiestablishment parties such as the Spanish Podemos. Since its foundation in 2014, this party has held more membership ballots for selecting regional party chairs and top candidates than the PSOE since 1998.

\section{Declaration of Conflicting Interests}

The author(s) declared no potential conflicts of interest with respect to the research, authorship, and/or publication of this article.

\section{Funding}

The author(s) received no financial support for the research, authorship, and/or publication of this article.

\section{ORCID iD}

Javier Astudillo (D) http://orcid.org/0000-0002-2265-4588

\section{Supplemental material}

Supplemental material for this article is available online.

\section{Notes}

1. In this article, we prefer the general term of "membership ballot"- usually called one-member-one-vote systems in Anglo-Saxon countries - when party members are asked to vote for leadership selection, candidate selection, or policy issues (Scarrow, 1999). We are also using the term "party primary," in particular when speaking about the selection of 
candidates for public offices (as an internal pre-contest before general elections take place).

2. The Sozialdemokratische Partei Deutschlands and the Partido Popular (PP; except for the period 1991-2008) have regional branches in all regions of their respective countries. By contrast, the Christlich Demokratische Union is absent in Bavaria, where its sister party, the Christlich-Soziale Union competes, and the Partido Socialista Obrero Español (PSOE) in Catalonia is federated with the Partit dels Socialistes de Catalunya.

3. The German Green Party is the only party at the federal level that has used party primaries for selecting its team of two electoral leaders for the federal elections in 2013 and 2017.

4. Up to 2016 , in the PP, the only two occasions in which party members had the opportunity to participate in the selection of party leadership was in the Balearic Islands in March 2010 and June 2012.

5. While membership ballots have been somehow more frequent in the three city-states of Hamburg, Berlin, and Bremen (11 out of 25 ballots), they have also been held in the very large regions (Baden-Württemberg, North Rhine Westphalia) and in the medium-sized Länder. Thus, there is no specific territorial pattern here.

6. As a former member of the PSOE executive declared in an interview held by one the authors on 6 June 2011 .

7. Testing political system factors such as cognitive mobilization or citizens' appraisal of more participatory mechanisms is not possible in a cross-sectional time-series analysis at the regional level. In any case, polls undertaken in Germany (by the CIVEY A German firm that makes survey) and Spain (by the Centro de Investigaciones Sociológicas) show that primaries are quite popular among the German and Spanish public.

8. The literature also mentions losing membership (Scarrow, 1999). Unfortunately, we did not have reliable data about the evolution of regional party membership in Spain.

9. We have also run statistical models using a rare events logistic regression as a robustness check. This estimator develops corrections for the biases in logistic regression that occur when explaining rare outcomes. Results were basically the same.

10. We have also tested whether the emergence of new parties in the regional assemblies affects the likelihood of holding primaries. It does not.

11. These figures are very similar to the ones of the German and Spanish national conferences (Kenig et al., 2015a: 60).

12. We have excluded from this comparison the PP party because this party has only held one membership ballot where the party chair ran (and without opposition).

13. We have performed again a random effects logistic regression.

14. The continued use of membership ballots also calls into question the possible counterargument that party elites progressively stopped using them once they realized that party members were less easy to control than they had initially expected.

\section{References}

Adam J and Merrill S (2008) Candidate and party strategies in two-stage elections beginning with a primary. American Journal of Political Science 52(2): 344-359.

Astudillo J (2014) La selección de los candidatos a las presidencias de los gobiernos autonómicos. In: Pallarés F (ed), Elecciones Autonómicas 2009-2012. Madrid: CIS, pp. 47-74.

Astudillo J (2015) Losers' second chances and control of the party machine: aspirants premiers in regional Spain. South European Society and Politics 20(2): 181-201.

Barberà $\mathrm{O}$, Lisi M and Rodríguez-Teruel J (2015) Democratising party leadership selection in Spain and Portugal. In: Giulia S, Seddone A and Venturino F (eds), Party Primaries in Comparative Perspective. Farnharm: Ashgate Publishing Limited, pp. 59-84.

Barnea S and Rahat G (2007) Reforming candidate selection methods: a three-level approach. Party Politics 13(3): 375-394.

Boucek F (2009) Rethinking factionalism: typologies, intra-party dynamics and three faces of factionalism. Party Politics 15(4): 455-485.

Chiru M, Gauja A, Gherghina S, et al. (2015) Explaining change in party leadership selection rules. In: Cross WP and Pilet JB (eds), The Politics of Party Leadership: A Cross-National Perspective. Oxford: Oxford University Press, pp. 31-49.

Cross WP (2013) Party leadership and intra-party democracy. In: Cross WP and Katz RS (eds), The Challenges of IntraParty Democracy. Oxford: Oxford University Press, pp. 100-116.

Cross WP and Pilet JB (2015) The Politics of Party Leadership: A Cross-National Perspective. Oxford: Oxford University Press.

Decker F and Küppers A (2015) Mehr Basisdemokratie wagen? Organisationsreformen der deutschen Mitgliederparteien im Vergleich. Zeitschrift für Staats-und Europawissenschaften [In German] 13: 397-419.

Detterbeck K (2013) The rare event of choice: party primaries in German land parties. German Politics 22: 270-287.

Gherghina S (2013) One-shot party primaries: the case of the Romanian social democrats. Politics 33(3): 185-195.

Hazan R and Rahat G (2010) Democracy Within Parties: Candidate Selection Methods and their Political Consequences. New York: Oxford University Press.

Hooghe L, Gary M, Arjan S, et al. (2016) Measuring Regional Authority: A Postfunctionalist Theory of Governance, Volume I. Oxford: Oxford University Press.

Jun U, Niedermayer O and Wiesendahl E (2009) Die Zukunft der Mitgliederpartei, [In German]. Opladen: Barbara Budrich.

Kamahlioglu O, Weitz-Shapiro R and Hirano S (2009) Why primaries in Latin American presidential elections? The Journal of Politics 71(1): 339-352.

Katz R and Mair P (1995) Changing models of party organization and party democracy: the emergence of the cartel party. Party Politics 1(1): 5-28.

Kenig O, Rahat G and Hazan R (2015b) Leadership selection versus candidate selection: similarities and differences. In: 
Giulia S, Seddone A and Venturino F (eds), Party Primaries in Comparative Perspective. Farnharm: Ashgate, pp. 21-40.

Kenig O, Rahat G and Tuttnauer O (2015a) Competitiveness of party leadership selection processes. In: Cross WP and Pilet JB (eds), The Politics of Party Leadership: A CrossNational Perspective. Oxford: Oxford University Press, pp. 50-72.

Lisi M (2010) The democratization of party leadership selection: the Portuguese experience. Portuguese Journal of Social Science 9(2): 127-149.

Lisi M, Freire A and Barberà $\mathrm{O}$ (2015) Leadership selection methods and party types. In: Cross WP and Pilet JB (eds), The Politics of Party Leadership: A Cross-National Perspective. Oxford: Oxford University Press, pp. 12-30.

Mair P (1997) Party System Change: Approaches and Interpretations. Oxford: Clarendon Press.

Neumann A (2013) Das “jahrzehnt der parteireform.” Ein Überblick über die Entwicklungen. In: von Alemann U, Morlok M and Spier T (eds), Parteien ohne Mitglieder? [In German]. Baden-Baden: Nomos, pp. 239-247.

Norris P (1999) Critical Citizens: Global Support for Democratic Government. Oxford: Oxford University Press.

Pallares F, Astudillo J and Verge T (2015) Spain: unresolved integration challenges in a party-led decentralization. In Detterbeck K, Renzsch W and Kincaid J (eds), Political Parties and Civil Society in Federal Countries. Don Mills: Oxford University Press, pp. 227-253.

Panebianco A (1988) Political Parties: Organization and Power. Cambridge: Cambridge University Press.

Pilet JB and Cross WP (2014) The Selection of Political Party Leaders in Contemporary Parliamentary Democracies: A Comparative Study. London: Routledge.
Ramiro L (2016) Effects of party primaries on electoral performance: the Spanish socialist primaries in local elections. Party Politics 22(1): 125-136.

Sandri G, Seddone A and Venturino F (2015) Party Primaries in Comparative Perspective. Farnharm: Ashgate.

Scarrow S (1999) Parties and the expansion of direct democracy, who benefits? Party Politics 5(3): 341-362.

Scarrow S (2015) Beyond Party Members. Changing Approaches to Partisan Mobilization. Oxford: Oxford University Press.

Van Biezen I (2003) Political Parties in New Democracies: Party Organization in Southern and East-Central Europe. Basingstoke: Palgrave Macmillan.

Ware A (1996) Political Parties and Party Systems. Don Mills: Oxford University Press.

\section{Author biographies}

Javier Astudillo is an associate professor in the Department of Political and Social Sciences of the Universitat Pompeu Fabra, Barcelona, Spain. He is the author of various works on interest groups and political parties, published peer-review international journals, and edited books. He is currently working on the relationship between party organization and chief executives at national and regional levels in Western parliamentarian democracies.

Klaus Detterbeck is a senior researcher at the University of Göttingen, Germany. He conducts research on political parties, federalism, and multilevel politics. He has authored Multi-Level Party Politics in Western Europe (Palgrave Macmillan, Houndmills, 2012) and coedited Political Parties and Civil Society in Federal Countries (Oxford University Press, Don Mills, Ontario, 2015). He is currently coediting the Handbook of Territorial Politics (to be published by Edward Elgar, Cheltenham, 2018). 